\title{
Isolation of a Bohle-like iridovirus from boreal toads housed within a cosmopolitan aquarium collection
}

\author{
Kwang Cheng ${ }^{1, *}$, Megan E. B. Jones ${ }^{2, *}$, James K. Jancovich ${ }^{3}$, Jennifer Burchell ${ }^{2}$, \\ Mark D. Schrenzel ${ }^{2}$, Drury R. Reavill ${ }^{4}$, Denise M. Imai ${ }^{4}$, Abby Urban ${ }^{5}$, \\ Maryanne Kirkendall ${ }^{6}$, Leslie W. Woods ${ }^{7}$, V. Gregory Chinchar ${ }^{1}$, Allan P. Pessier ${ }^{2, * *}$ \\ ${ }^{1}$ Department of Microbiology, University of Mississippi Medical Center, Jackson, MS 39216, USA \\ ${ }^{2}$ Amphibian Disease Laboratory, Wildlife Disease Laboratories, Institute for Conservation Research, San Diego Zoo Global, \\ San Diego, CA 92112-0551, USA \\ ${ }^{3}$ Department of Biological Sciences, California State University San Marcos, San Marcos, CA 92096, USA \\ ${ }^{4}$ Zoo/Exotic Pathology Service, West Sacramento, CA 95605, USA \\ ${ }^{5}$ National Mississippi River Museum and Aquarium, Dubuque, IA 52001, USA \\ ${ }^{6}$ Colonial Terrace Animal Hospital, Dubuque, IA 52001, USA \\ ${ }^{7}$ California Animal Health and Food Safety Laboratory, Davis, CA 95616, USA
}

\begin{abstract}
A captive 'survival assurance' population of 56 endangered boreal toads Anaxyrus boreas boreas, housed within a cosmopolitan collection of amphibians originating from Southeast Asia and other locations, experienced high mortality (91\%) in April to July 2010. Histological examination demonstrated lesions consistent with ranaviral disease, including multicentric necrosis of skin, kidney, liver, spleen, and hematopoietic tissue, vasculitis, and myriad basophilic intracytoplasmic inclusion bodies. Initial confirmation of ranavirus infection was made by Taqman real-time PCR analysis of a portion of the major capsid protein (MCP) gene and detection of iridovirus-like particles by transmission electron microscopy. Preliminary DNA sequence analysis of the MCP, DNA polymerase, and neurofilament protein (NFP) genes demonstrated highest identity with Bohle iridovirus (BIV). A virus, tentatively designated zoo ranavirus (ZRV), was subsequently isolated, and viral protein profiles, restriction fragment length polymorphism analysis, and next generation DNA sequencing were performed. Comparison of a concatenated set of 4 ZRV genes, for which BIV sequence data are available, with sequence data from representative ranaviruses confirmed that ZRV was most similar to BIV. This is the first report of a BIV-like agent outside of Australia. However, it is not clear whether ZRV is a novel North American variant of BIV or whether it was acquired by exposure to amphibians co-inhabiting the same facility and originating from different geographic locations. Lastly, several surviving toads remained PCR-positive $10 \mathrm{wk}$ after the conclusion of the outbreak. This finding has implications for the management of amphibians destined for use in reintroduction programs, as their release may inadvertently lead to viral dissemination.
\end{abstract}

KEY WORDS: Ranavirus · Boreal toads $\cdot$ Bohle iridovirus $\cdot$ Viral taxonomy $\cdot$ Survival assurance colonies

Resale or republication not permitted without written consent of the publisher

\section{INTRODUCTION}

Viruses within the genus Ranavirus (family Iridoviridae) are large double-stranded DNA viruses that infect amphibians, fish, and reptiles (Chinchar 2002,
Chinchar et al. 2009). Since the description of the type species Frog virus 3 (FV3) in 1965, ranaviruses have emerged as significant pathogens of wild amphibians, with mass mortality events observed in frogs, salamanders, and turtles (Cunningham et al. 
1996, Bollinger et al. 1999, Green et al. 2002, Docherty et al. 2003, Johnson et al. 2008). Unlike the chytrid fungus Batrachochytrium dendrobatidis, ranaviruses have not yet been associated with population extinctions. However, ranaviruses are a special concern for isolated populations that experience recurrent mortality events, as these might lead to local extirpation (Gray et al. 2009, Teacher et al. 2010). Furthermore, because of their adverse impact on commercially and ecologically important ectothermic vertebrates, the World Organization for Animal Health has placed ranavirus infections on the list of notifiable animal diseases (Schloegel et al. 2010).

Currently there are 6 recognized species within the genus Ranavirus (FV3, Ambystoma tigrinum virus [ATV], Bohle iridovirus [BIV], European catfish virus $[\mathrm{ECV}]$, Epizootic hematopoietic necrosis virus [EHNV], and Santee-Cooper ranavirus [SCRV]) as well as numerous isolates and strains of the above species (Chinchar et al. 2009, 2011, Jancovich et al. 2012). Taxonomically, the delineation of ranavirus species is based on multiple criteria, including sequence analysis of key viral genes, viral host range, geographic distribution of the virus, and viral phylogeny. An additional approach employs dot plot analyses to compare gene content and gene order among species and isolates. With this method, the genus Ranavirus can be ordered into 4 groups based upon genomic organization: (1) FV3-like viruses (FV3, tiger frog virus [TFV], soft shell turtle iridovirus [STIV], Rana grylio virus [RGV]), (2) ATV-like viruses (ATV, EHNV, European sheatfish virus [ESV]), (3) Singapore grouper iridovirus (SGIV)-like viruses (SGIV, grouper iridovirus [GIV]), and (4) common midwife toad virus (CMTV) (Jancovich et al. 2010, Mavian et al. 2012).

FV3-like viruses and CMTV infect anurans and have been detected in North and South America, Europe, and Asia (Granoff et al. 1965, 1966, Wolf et al. 1968, Cunningham et al. 1996, 2007a,b, Zhang et al. 2001, Docherty et al. 2003, Fox et al. 2006, Mazzoni et al. 2009). However, indicative of their broad host range, recent infections with FV3-like viruses have also been observed in salamanders, turtles, and fish, and some FV3-like viruses can also infect animals from different taxonomic classes (Mao et al. 1997, 1999a, Johnson et al. 2008, Huang et al. 2009, Chinchar \& Waltzek 2014), Likewise, ATV-like viruses were initially detected in North American tiger salamanders, but have been shown to infect frogs after experimental infection (Jancovich et al. 1997, Bollinger et al. 1999, Schock et al. 2008). In contrast to the former 2 groups, SGIV-like viruses infect only fish and represent the most distantly related group of ranaviruses (Song et al. 2004).

The taxonomic status of BIV has yet to be resolved. BIV, first detected in captive ornate burrowing frogs Lymnodynastes ornatus wild-caught as larvae in Queensland, Australia (Speare \& Smith 1992), was designated a species based on its apparent confinement to Australian amphibians. However, like other ranaviruses, BIV appears to have a broad host range and is capable of infecting fish (barramundi Lates calcarifer) and several other anuran species after experimental infection (Moody \& Owens 1994, Cullen \& Owens 2002). Recently, a second BIV-like virus, Mahaffey Road virus, was described from captive frogs (Litoria splendida and L. caerulea) in Australia (Weir et al. 2012). To date, however, BIV-like viruses have not been detected outside Australia.

Ranaviral disease outbreaks have been increasingly recognized in captive amphibians, especially those reared under intensive aquaculture conditions (Weng et al. 2002, Majji et al. 2006, Miller et al. 2007, Mazzoni et al. 2009, Geng et al. 2011) or in pet, zoo, and aquarium collections (Miller et al. 2008, Pasmans et al. 2008, Driskell et al. 2009). However, it is possible that outbreaks of ranaviral disease have been overlooked in captive settings because clinical and pathological findings overlap other amphibian diseases and, until recently, ready access to specific diagnostic tests was limited (Pessier \& Mendelson 2010). The ability to recognize ranaviral infections is important because conservation efforts often include formation of survival assurance populations for breeding and possible reintroduction of animals into the wild (Zippel et al. 2011). If assurance populations come into contact with ectothermic vertebrates that harbor ranaviruses, there is the potential for infection. Not only could this pose a risk for the sustainability of individual assurance populations, but it may also facilitate movement of ranaviruses to wild amphibian populations via discharge of wastewater, fomites, or the animals themselves.

In this report we describe a severe outbreak caused by a BIV-like agent in a captive survival assurance population of endangered boreal toads Anaxyrus boreas boreas. The ranavirus isolated here, designated zoo ranavirus (ZRV), represents the first isolation of a BIV-like virus outside of Australia. Moreover, the observation that surviving toads contained ZRV DNA 10 wk after the resolution of the outbreak is of concern for amphibian reintroduction programs, because this suggests that ZRV exposure may lead to persistent infection and that ostensibly healthy frogs may serve as vehicles for viral transmission. 


\section{MATERIALS AND METHODS}

\section{Case history}

The outbreak occurred in a captive survival assurance population of 56 boreal toads housed at an aquarium in Iowa (USA). The toads were kept in an off-exhibit holding area in 6 glass aquariums that shared water in a closed re-circulating system. Housed in the same room with a separate water handling system were 135 individuals representing 10 other anuran species. These included species endemic to Madagascar (Mantella viridis, M. pulchra, and Scaphiophryne gottlebei), continental Africa (Hyperolius sp.), Southeast Asia (Nyctixalus pictus, Megophrys nasuta, and Calluella guttulata), and South America (Phyllobates bicolor and Melanophryniscus stelzneri; see Table 2 for common names). No new animals had been introduced into the holding area for at least $1 \mathrm{yr}$ prior to the outbreak.

In late April 2010, boreal toads in a single tank exhibited cutaneous hyperemia, vesicles, and erosions. Affected animals died 1 to $3 \mathrm{~d}$ after the appearance of clinical signs. To prevent the spread of infection, the tanks were removed from the re-circulating system. By early May, deaths were occurring in other tanks and empirical treatment with antibiotics (ceftazidime) and antifungal drugs (itraconazole baths) was initiated. Despite treatment, 51 of 56 toads (91\%) died between April and July. During this time, sporadic deaths occurred in other anuran species housed in the room, including 1 adult $M$. nasuta, 8 recently metamorphosed $M$. viridis, and $1 S$. gottlebei. None exhibited clinical signs similar to the boreal toads. In September 2010, 10 wk after the last death, the 5 surviving boreal toads and 41 individuals representing approximately $20 \%$ of the population of each anuran species housed in the same room were euthanized by overexposure to tricaine methanesulfonate (MS222) and analyzed as described below.

\section{Histopathology}

Toads that died between April and July were either fixed whole in $10 \%$ neutral buffered formalin for histology or tissues were frozen for subsequent PCR
Table 1. Summary of boreal toad Anaxyrus boreas boreas tissues sampled during the outbreak in 2010. EM: electron microscopy; H: formalinfixed tissue for histology; L: frozen liver; P: pooled frozen liver, kidney, and skin; Pos: positive; nt: not tested; A: abscess; B: systemic bacterial infection; IB: inclusion bodies; $\mathrm{N}$ : tissue necrosis; U: no histological lesions; V: the only lesion was necrotizing vasculitis

\begin{tabular}{|c|c|c|c|c|c|c|}
\hline $\begin{array}{l}\text { Toad } \\
\text { no. }\end{array}$ & $\begin{array}{c}\text { Date of } \\
\text { death }\end{array}$ & $\begin{array}{c}\text { Sample } \\
\text { type }\end{array}$ & RT-PCR & $\begin{array}{l}\text { Virus } \\
\text { isolation }\end{array}$ & EM & $\begin{array}{l}\text { Histological } \\
\text { findings }\end{array}$ \\
\hline 1 & $26 \mathrm{Apr}$ & $\mathrm{H}$ & nt & $\mathrm{nt}$ & nt & $\mathrm{N}, \mathrm{IB}$ \\
\hline 2 & $26 \mathrm{Apr}$ & $\mathrm{H}$ & $\mathrm{nt}$ & $\mathrm{nt}$ & nt & N, IB \\
\hline 3 & $28 \mathrm{Apr}$ & $\mathrm{H}$ & $\mathrm{nt}$ & $\mathrm{nt}$ & nt & $\mathrm{N}, \mathrm{IB}, \mathrm{B}$ \\
\hline 4 & 29 Apr & $\mathrm{H}$ & nt & $\mathrm{nt}$ & nt & N, IB \\
\hline 5 & 03 May & $\mathrm{H}, \mathrm{L}$ & Pos & nt & Pos & N, IB \\
\hline 6 & 04 May & $\mathrm{H}$ & $\mathrm{nt}$ & nt & nt & $\mathrm{N}, \mathrm{IB}$ \\
\hline 7 & 05 May & $\mathrm{H}$ & $\mathrm{nt}$ & $\mathrm{nt}$ & nt & $\mathrm{N}, \mathrm{IB}, \mathrm{B}$ \\
\hline 8 & 13 May & $\mathrm{P}$ & Pos & nt & nt & nt \\
\hline 9 & 15 May & $\mathrm{P}$ & Pos & $\mathrm{nt}$ & nt & $\mathrm{nt}$ \\
\hline 10 & 17 May & $\mathrm{P}$ & Pos & nt & nt & nt \\
\hline 11 & 18 May & $\mathrm{P}$ & Pos & $\mathrm{nt}$ & nt & nt \\
\hline 12 & 20 May & $\mathrm{H}$ & nt & $\mathrm{nt}$ & nt & $\mathrm{U}$ \\
\hline 13 & 20 May & $\mathrm{H}$ & nt & nt & nt & N, IB \\
\hline 14 & 20 May & $\mathrm{H}$ & nt & $\mathrm{nt}$ & nt & V \\
\hline 15 & 22 May & $\mathrm{P}$ & Pos & Pos & nt & nt \\
\hline 16 & 22 May & $\mathrm{P}$ & Pos & nt & nt & nt \\
\hline 17 & 22 May & $\mathrm{P}$ & Pos & nt & $\mathrm{nt}$ & nt \\
\hline 18 & 24 May & $\mathrm{P}$ & $\operatorname{Pos}^{a}$ & Pos & nt & $\mathrm{nt}$ \\
\hline 19 & 24 May & $\mathrm{P}$ & Pos & Pos & $\mathrm{nt}$ & nt \\
\hline 20 & 24 May & $\mathrm{P}$ & Pos & nt & nt & nt \\
\hline 21 & 25 May & $\mathrm{P}$ & Pos & nt & nt & nt \\
\hline 22 & 27 May & $\mathrm{P}$ & $\operatorname{Pos}^{\mathrm{a}}$ & Pos & $\mathrm{nt}$ & $\mathrm{nt}$ \\
\hline 23 & 27 May & $\mathrm{P}$ & Pos & $\mathrm{nt}$ & nt & nt \\
\hline 24 & 24 June & $\mathrm{H}$ & $\mathrm{nt}$ & nt & $\mathrm{nt}$ & A, IB \\
\hline 25 & 26 June & $\mathrm{H}$ & $\mathrm{nt}$ & $\mathrm{nt}$ & $\mathrm{nt}$ & A, IB \\
\hline 26 & 26 Jun & $\mathrm{H}$ & $\mathrm{nt}$ & $\mathrm{nt}$ & nt & N, IB \\
\hline 27 & 28 Jun & $\mathrm{H}$ & nt & nt & nt & A, IB \\
\hline 28 & 28 Jun & $\mathrm{H}$ & $\mathrm{nt}$ & $\mathrm{nt}$ & nt & N, IB \\
\hline 29 & 28 Jun & $\mathrm{H}$ & $\mathrm{nt}$ & $\mathrm{nt}$ & $\mathrm{nt}$ & $\mathrm{N}, \mathrm{IB}, \mathrm{B}$ \\
\hline 30 & $01 \mathrm{Jul}$ & $\mathrm{H}$ & nt & nt & nt & A \\
\hline 31 & $01 \mathrm{Jul}$ & $\mathrm{H}$ & nt & $\mathrm{nt}$ & $\mathrm{nt}$ & $\mathrm{N}, \mathrm{IB}, \mathrm{B}$ \\
\hline 32 & $04 \mathrm{Jul}$ & $\mathrm{H}$ & $\mathrm{nt}$ & $\mathrm{nt}$ & $\mathrm{nt}$ & A, IB \\
\hline 33 & $12 \mathrm{Jul}$ & $\mathrm{H}$ & nt & nt & nt & $A, B$ \\
\hline 34 & $14 \mathrm{Jul}$ & $\mathrm{H}$ & $\mathrm{nt}$ & nt & nt & A \\
\hline
\end{tabular}

analysis and virus isolation (Table 1). Necropsies were performed on fixed carcasses and, in most cases, samples of skin, tongue, lung, esophagus, stomach, small and large intestine, liver, pancreas, spleen, larynx, thymus, kidneys, gonad, urinary bladder, brain, and bone were collected for histological examination. Tissues from other species housed in the toad room as well as animals euthanized in September 2010 were similarly collected. Tissues were routinely processed and embedded in paraffin, sectioned at $5 \mu \mathrm{m}$, and stained with hematoxylin and eosin. Additional stains were used as needed, including Fite-Faraco acid-fast, Gram's stain, Grocott's methenamine silver, and periodic acid Schiff. 


\section{Real-time PCR}

Postmortem tissue samples and oropharyngeal swabs Dryswab $^{\text {TM }}$ Fine Tip MW113, Advantage Bundling SP/Medical Wire and Equipment) were screened for the presence of ranaviral DNA by Taqman real-time polymerase chain reaction (RT-PCR). Samples included (1) frozen $\left(-20^{\circ} \mathrm{C}\right)$ liver from boreal toad no. 18 and pooled liver, kidney, and skin collected from boreal toads 8 to 11 and 15 to 23 that died during the outbreak (Table 1); (2) swabs collected at the time of the outbreak from 1 toad in each of the 6 boreal toad tanks and from healthy $M$. viridis $(\mathrm{n}=2)$, $N$. pictus $(\mathrm{n}=1), M$. nasuta $(\mathrm{n}=2)$, and $C$. guttulata ( $\mathrm{n}=1$ ) housed in the boreal toad room; and (3) oropharyngeal swabs and pooled liver, kidney, and skin collected $10 \mathrm{wk}$ after the conclusion of the outbreak from 5 surviving boreal toads and 41 other frogs housed in the boreal toad room (Table 2).

DNA was extracted from rayon-tipped swabs and tissues using DNeasy Blood and Tissue Kits (Qiagen), and conserved regions of the ranavirus major capsid protein (MCP) gene were amplified following the methods of Pallister et al. (2007). RT-PCR assays were performed using the ABI Real-time 7900HT system. Each $20 \mu \mathrm{l}$ reaction was run in triplicate and contained the following reagents: $10 \mu \mathrm{l}$ of $2 \times$ Taqman Environmental Master Mix (Applied Biosystems), $900 \mathrm{nM}$ of each primer, $250 \mathrm{nM}$ of the Taqman FAM MGB probe (Applied Biosystems), and $5 \mu$ of DNA. PCR assay conditions were $50^{\circ} \mathrm{C}$ for $2 \mathrm{~min}, 95^{\circ} \mathrm{C}$ for $10 \mathrm{~min}$, and then 55 cycles consisting of $95^{\circ} \mathrm{C}$ for $15 \mathrm{~s}$ and $60^{\circ} \mathrm{C}$ for $1 \mathrm{~min}$. A threshold of 0.2 was set. Samples that amplified at a cycle threshold $(\mathrm{Ct})$ value of $\geq 40$ were considered negative. Samples that amplified in only 1 or 2 wells were re-run in quintuplicate, and those amplifying at $\mathrm{Ct}$ values of $<40$ in 3 or more wells were considered positive.

\section{Conventional PCR and DNA sequence analysis}

Based on the results of initial qPCR screening, conventional PCR followed by DNA sequence and phylogenetic analysis of the resulting products was performed on (1) tissue samples (pooled liver, kidney, and skin) from 2 moribund boreal toads (nos. 18 and 22; Table 1) and an oropharyngeal swab from an apparently healthy $M$. nasuta obtained during the outbreak and (2) tissue samples from both an asymptomatic boreal toad and M. stelzneri collected $10 \mathrm{wk}$ after the end of the outbreak (Table 2).
Table 2. RT PCR survey of boreal toads Anaxyrus boreas boreas and co-housed amphibians following the outbreak. Boreal toads that survived the April to July outbreak along with a subset of anuran species representing $20 \%$ of those co-housed in the same room were monitored for the presence of ranaviral DNA. Samples obtained from either oropharyngeal swabs or pooled liver, kidney, and skin were analyzed by Taqman real-time PCR. The fraction testing positive for ranavirus is shown. nt: not tested

\begin{tabular}{|c|c|c|}
\hline \multirow{2}{*}{ Species } & \multicolumn{2}{|c|}{ Fraction positive } \\
\hline & Swabs & Tissue \\
\hline Boreal toad & $0 / 5$ & $3 / 5^{\mathrm{a}}$ \\
\hline $\begin{array}{l}\text { Bumblebee toad } \\
\text { Melanophryniscus stelzneri }\end{array}$ & $\mathrm{nt}$ & $1 / 5^{\mathrm{b}}$ \\
\hline $\begin{array}{l}\text { Cinnamon frog } \\
\text { Nyctixalus pictus }\end{array}$ & nt & $0 / 7$ \\
\hline $\begin{array}{l}\text { Green mantella } \\
\text { Mantella viridis }\end{array}$ & $0 / 12$ & $0 / 14$ \\
\hline $\begin{array}{l}\text { Malayan horned frog } \\
\text { Megophrys nasuta }\end{array}$ & $0 / 2$ & $0 / 2$ \\
\hline $\begin{array}{l}\text { Red rain frog } \\
\text { Scaphiophryne gottlebei }\end{array}$ & $0 / 6$ & $0 / 6$ \\
\hline $\begin{array}{l}\text { Reed frog } \\
\text { Hyperolius sp. }\end{array}$ & $0 / 1$ & $0 / 1$ \\
\hline $\begin{array}{l}\text { Splendid mantella } \\
\text { Mantella pulchura }\end{array}$ & $0 / 1$ & $0 / 1$ \\
\hline $\begin{array}{l}\text { Vietnamese burrowing frog } \\
\text { Calluella guttulata }\end{array}$ & $0 / 4$ & $0 / 4$ \\
\hline $\begin{array}{l}\text { Bicolor dart frog } \\
\text { Phyllobates bicolor }\end{array}$ & $0 / 1$ & $0 / 1$ \\
\hline $\begin{array}{l}\text { The cycle threshold }(\mathrm{Ct}) \text { va } \\
\text { real-time PCR ranged from } \\
\text { ues from tissues of sick toad } \\
\text { ranged from } 10 \text { to } 15 \text {. Co } \\
\text { sequencing was used to co } \\
\text { result in } 1 \text { of these toads }\end{array}$ & $\begin{array}{l}\text { les obtai } \\
7 \text { to } 39 \text {. } \\
\text { dying d } \\
\text { ivention } \\
\text { firm the }\end{array}$ & $\begin{array}{l}\text { Taqman } \\
\text { st, Ct val- } \\
\text { outbreak } \\
\text { nd DNA } \\
\text { RT-PCR }\end{array}$ \\
\hline $\begin{array}{l}{ }^{b} \text { The RT-PCR Ct value was } 3 \\
\text { DNA sequencing confirmed }\end{array}$ & $\begin{array}{l}\text { 5.4. Cont } \\
\text { the posit }\end{array}$ & $\begin{array}{l}\mathrm{PCR} \text { and } \\
\mathrm{CR} \text { result }\end{array}$ \\
\hline
\end{tabular}

Primer sets targeting the MCP (forward: 5'-CGC AGT CAA GGC CTT GAT GT-3'; reverse: 5'-AAA GAC CCG TTT TGC AGC AAA C-3'), DNA polymerase (DNApol-F: 5'-GTC TAY CAG TGG TTT TGC GAC-3'; DNApol-R: 5'-TCG TCT CCG GGY CTG TCT TT-3'), and the neurofilament triplet H1like (NFP-F: 5'-CCA AAG ACC AAA GAC CAG-3'; NFP-R: 5'-GTT GGT CTT TGG TCT CGC TC-3') genes were used as previously described (Hyatt et al. 2000, Holopainen et al. 2009). The expected sizes of the amplicons from the above primer sets were 585, 560, and $639 \mathrm{bp}$, respectively. To acquire additional sequence information, a nested PCR protocol was designed based on initial neurofilament protein (NFP) sequence data from boreal toads and 
the FV3 sequence (GenBank AY548484.1). Round 1 of the nested PCR utilized the above described NFP-F and NFP-R primers and the round 2 primer set was BorealToadNF1 (5'-ATA TCA TGG GAG GCG CTG GG-3') and BorealToad705R (5'-CTC TCT CAA AGG ATT CGT CAG AC-3'). The expected size of the boreal toad NFP amplicon was $705 \mathrm{bp}$. Each sample was run in a $25 \mu \mathrm{l}$ reaction containing $12.5 \mu \mathrm{l}$ MyTaq HS Red mix 2× (Bioline), $0.2 \mu \mathrm{M}$ of each primer, $2 \mu \mathrm{l} \mathrm{DNA}$, and $10.1 \mu \mathrm{l}$ nuclease-free water. The neurofilament PCR reactions required the addition of $0.28 \mathrm{mg} \mathrm{ml}^{-1}$ of bovine serum albumin. PCR conditions for amplification of the MCP and NFP were $95^{\circ} \mathrm{C}$ for 5 min; then 40 cycles consisting of $95^{\circ} \mathrm{C}$ for $45 \mathrm{~s}, 55^{\circ} \mathrm{C}$ for $45 \mathrm{~s}$, and $72^{\circ} \mathrm{C}$ for $1 \mathrm{~min}^{\circ}$ and a final extension phase of $72^{\circ} \mathrm{C}$ for $10 \mathrm{~min}$. PCR parameters for the DNApol product were identical, but used an annealing temperature of $50^{\circ} \mathrm{C}$. The amplicons were separated on $1 \%$ agarose gels and visualized under a UV light at a wavelength of $312 \mathrm{~nm}$. Bands of expected size were excised from the gel and purified using Ultrafree-DA Centrifugal Filter Units (Millipore). PCR products were cloned using the TOPO TA cloning system (Invitrogen) following the manufacturer's guidelines. Plasmid DNA containing sequence inserts was isolated using the Zymo Miniprep plasmid DNA extraction kit. Viral inserts were either sequenced using a Beckman Coulter CEQ 8000 Genetic Analysis system version 9.0 or outsourced to Genewhiz (San Diego, CA) and Eton Bioscience (San Diego, CA), which utilized ABI Automated Sequencers. Cloned inserts were sequenced using $\mathrm{T} 7$ promotor and M13R universal primers; plasmid sequences were trimmed and consensus alignments were created using MacVector. The consensus alignments were compared to previously published ranavirus sequences using NCBI BLAST analysis (www.blast.ncbi.nlm.nih.gov; Altschul et al. 1990).

\section{Transmission electron microscopy}

Samples of formalin-fixed skin and kidney from toad 5 (Table 1) were processed for transmission electron microscopy. Tissues were transferred to half-strength modified Karnovsky's fixative, postfixed in $2 \%$ osmium tetroxide with $2.5 \%$ potassium ferrocyanide, and embedded in Eponate-12 epoxy resin (Ted Pella). Ultrathin sections were stained with uranyl acetate and lead citrate and examined on a Zeiss 906E transmission electron microscope.

\section{Virus isolation}

Virus was isolated from liver, kidney, and skin samples from toads 18, 19, and 22 and from liver and skin from toad 15 (Table 1). Pooled tissues from each animal were homogenized manually in $5 \mathrm{ml}$ Dulbecco's modified Eagle's medium containing $4 \%$ fetal bovine serum (DMEM4). The homogenate was clarified by low speed centrifugation (200 × g, 5 min, Hermle Model Z380 centrifuge), and $1 \mathrm{ml}$ of the supernatant was used to inoculate $75 \mathrm{~cm}^{2}$ flasks containing confluent monolayers of fathead minnow cells (FHM, Pimephales promelas; American Type Culture Collection, ATCC No. CCL42). The inoculum was allowed to adsorb at room temperature for $1 \mathrm{~h}$, after which an additional $10 \mathrm{ml}$ of DMEM4 were added and the culture incubated at $26^{\circ} \mathrm{C}$ in a humidified incubator in $5 \%$ $\mathrm{CO}_{2} / 95 \%$ air. At the end of the first week, cytopathic effect (CPE) was not observed. The cultures were subjected to 3 cycles of freeze-thaw, clarified as above, and a second set of FHM flasks was infected. Within $1 \mathrm{wk}$ after this blind passage, CPE was evident in 3 of the 4 cultures, and 1 culture (from toad 18) was selected. Virus from this culture was used to prepare a virus stock, designated ZRV no. 22512 .

\section{Viral protein synthesis}

To compare the protein profiles of ZRV and FV3, FHM cells grown in $35 \mathrm{~mm}$ culture dishes were mock-infected or infected with ZRV and FV3 at a multiplicity of infection (MOI) of 20 plaque-forming units (PFU) cell ${ }^{-1}$. Virus was allowed to adsorb for $1 \mathrm{~h}$ at $26^{\circ} \mathrm{C}$, at which time $2 \mathrm{ml}$ DMEM4 were added and incubation continued at $26^{\circ} \mathrm{C}$ in a humidified $\mathrm{CO}_{2}$ incubator. From 6 to $8 \mathrm{~h}$ post infection (p.i.), cells were radiolabeled with methionine-cysteine free Eagle's minimum essential medium with Earle's salts containing $20 \mu \mathrm{Ci} \mathrm{ml}{ }^{-1}\left[{ }^{35} \mathrm{~S}\right]$ methionine-cysteine (EasyTag Express Protein Labeling Mix, PerkinElmer). At $8 \mathrm{~h} \mathrm{p.i.,} \mathrm{the} \mathrm{medium} \mathrm{containing} \mathrm{the}\left[{ }^{35} \mathrm{~S}\right]$ methionine-cysteine was removed and the cell monolayer disrupted using $300 \mu \mathrm{l}$ Direct Sample Buffer $(125 \mathrm{mM}$ Tris- $\mathrm{HCl}, \mathrm{pH} 6.8,10 \%$ glycerol, $2 \%$ SDS, $0.02 \%$ 2-mercaptoethanol, $0.01 \%$ bromophenol blue) and boiled for 5 min (Mao et al. 1997). Radiolabeled proteins were separated by electrophoresis on $10 \%$ SDS-PAGE gels (Laemmli 1970) and visualized by phosphorimaging (Personal Molecular Imager, BioRad). 


\section{Preparation of ZRV DNA}

Eight $150 \mathrm{~cm}^{2}$ flasks containing confluent monolayers of FHM cells propagated in Eagle's minimum essential medium with Hank's salts and $4 \%$ fetal bovine serum (HMEM4) were each infected with ZRV at an MOI of $0.01 \mathrm{PFU}^{\mathrm{C}} \mathrm{Cll}^{-1}$. Virus was allowed to adsorb for $1 \mathrm{~h}$, after which $30 \mathrm{ml}$ HMEM4 were added to each flask and the cultures incubated at $25^{\circ} \mathrm{C}$. When CPE was extensive ( $4 \mathrm{~d}$ p.i.), viruscontaining media and cells were collected, pooled, subjected to 3 freeze-thaw cycles, and clarified by centrifugation $(1000 \times g$ for $15 \mathrm{~min})$ in a Sorval GSA rotor. The supernatant was collected and the cell pellet resuspended in $20 \mathrm{ml}$ HMEM4 and disrupted by sonication for $2 \mathrm{~min}$, and the suspension was clarified by centrifugation. The first and second virus-containing supernatant fractions were combined and the titer determined by plaque assay on FHM monolayers using $0.75 \%$ methylcellulose in DMEM4 as the overlay medium.

ZRV-containing medium $\left(4.7 \times 10^{6} \mathrm{PFU} \mathrm{\textrm {ml } ^ { - 1 }}\right)$ was used to isolate viral DNA for restriction fragment length polymorphism (RFLP) analysis and DNA sequencing as described previously (Majji et al. 2006). Briefly, $300 \mathrm{ml}$ of clarified virus-containing medium were centrifuged for $60 \mathrm{~min}(47090 \times$ $g$ at $4^{\circ} \mathrm{C}$ ) using a Beckman Type 55.2 Ti rotor, and the resulting virion pellets were resuspended in $10 \mathrm{ml}$ reticulocyte standard buffer (RSB) (10 mM Tris- $\mathrm{HCl}, \mathrm{pH}$ 7.6, $10 \mathrm{mM} \mathrm{KCl}, 1.5 \mathrm{mM} \mathrm{MgCl}_{2}$ ). To isolate viral DNA, $3 \mathrm{ml}$ of concentrated virions were treated with DNAse (200 $\mu \mathrm{g} \mathrm{ml}^{-1}$, Sigma) in the presence of $10 \mathrm{mM} \mathrm{MgCl}$ for $60 \mathrm{~min}$ at $37^{\circ} \mathrm{C}$. After $1 \mathrm{~h}$, the reaction was stopped by adding EDTA to a final concentration of $50 \mathrm{mM}$, and the virion suspension was layered over a $7 \mathrm{ml} 20 \%$ (w/w) sucrose-RSB cushion and centrifuged (47090 $\times g$ for $90 \mathrm{~min}$ at $4^{\circ} \mathrm{C}$ ) using a Beckman SW41 rotor. The overlay was removed by aspiration and the virion pellet was resuspended in TE buffer (10 mM Tris-HCl, pH 7.6, 1 mM EDTA). Virions were digested overnight in the presence of $1 \%$ SDS and $100 \mu \mathrm{g} \mathrm{ml} \mathrm{m}^{-1}$ Proteinase K (Qiagen) at $37^{\circ} \mathrm{C}$, and viral DNA, extracted using phenolchloroform, was resuspended in $30 \mu \mathrm{l}$ TE and quantified spectrophotometrically.

\section{RFLP analysis}

ZRV and FV3 genomic DNA (5 $\mu \mathrm{g}$ ) were digested overnight at $37^{\circ} \mathrm{C}$ with 10 units HindIII. Digested
DNA was separated by electrophoresis on $1 \%$ agarose gels at $120 \mathrm{~V}$ for $\sim 8 \mathrm{~h}$, and visualized by staining with ethidium bromide (Mao et al. 1997).

\section{DNA sequence analysis}

Viral genomic DNA was subjected to next generation DNA sequencing using Illumina HiSeq 2000 technology at The Scripps Research Institute NGS Core Facility (La Jolla, CA). One microgram of input DNA was processed using the Illumina TruSeq $^{\mathrm{TM}}$ protocol. Library fragments (200-400 bp in length) were generated using the Covaris $^{\mathrm{TM}} \mathrm{S} 2$ ultrasonicator system (Life Technologies). Sheared genomic DNA fragments were end-repaired using the End Repair mix, and a single ' $A$ ' base was added to the blunt-end fragments of each strand using the A-tailing mix. Each adapter contains a ' $\mathrm{T}$ ' base overhang that was then ligated to the Atailed fragmented DNA. Following ligation, the genomic DNA library was purified using the Agencourt SPRI system (Beckman Coulter) and subjected to 6 cycles of PCR amplification using TruSeq PCR primers according to the manufacturer's instructions. PCR products (350-500 bp) were selected after electrophoresis through a $2 \%$ agarose gel. A pooled source of $7 \mathrm{pM}$ of the generated library was loaded into the lane for paired end flowcells, and sequenced for $101 \times 2$ (paired end sequencing) base reads plus 7 bases of barcode sequence. Fastq data were generated using Consensus Assessment of Sequence And Variation (CASAVA) v1.8.2 (Illumina), and the resulting sequences were mapped onto the FV3 genomic DNA backbone and arranged into 15 contigs using the GS DeNovo assembler (version 2.0.00, Roche). ZRV genes encoding the MCP, $18 \mathrm{kDa}$ immediateearly protein $(18 \mathrm{~K})$, a $46 \mathrm{kDa}$ protein $(46 \mathrm{~K}), \mathrm{NFP}$, and thymidine kinase (TK) were identified using ORF Finder (NCBI), and the sequence data were entered into GenBank under the following accession numbers: 18K, KF703533.1; 46K, KF703531.1; TK, KF703532.1; MCP, KF699143.1; NFP, KF 703530.1. Multiple alignments were conducted using CLUSTAL W (Larkin et al. 2007) within Megalign (DNASTAR) and MUSCLE within MEGA5 (Tamura et al. 2011). Using MEGA5 and MUSCLE alignments, evolutionary history was inferred employing the maximum-likelihood method and the JTT matrix model. For these analyses, all residue positions containing gaps or missing data were eliminated. 


\section{RESULTS}

\section{Histopathology}

Histological examination of tissues from toads that died early in the outbreak (April and May) demonstrated severe systemic disease with necrosis in multiple organs and the frequent observation of basophilic intracytoplasmic inclusion bodies 2 to $5 \mu \mathrm{m}$ in diameter suggestive of ranavirus infection (Gray et al. 2009). Toads dying later in the outbreak (June and July) had similar findings, but with fewer inclusion bodies and frequent observation of bacterial abscesses in the skin and viscera.

Necrosis was most prominent in the skin, hematopoietic tissue, blood vessels, liver, kidney, spleen, and gastrointestinal tract. In the skin, early lesions showed epidermal hydropic degeneration and spongiosis with vesicle formation (Fig. 1A) which progressed to full-thickness epidermal necrosis (Fig. 1B). Inclusion bodies were inconsistently observed in the skin and when present were found in keratinocytes adjacent to vesicles or areas of necrosis. Hemato- poietic tissue necrosis was observed in intravascular leukocytes (monocytes and granulocytes), bone marrow (Fig. 1C), and the interstitium of the kidney. Necrosis of circulating leukocytes was best appreciated in hepatic sinusoids as dust-like karyorrhectic debris (Fig. 1D). Vascular lesions (necrotizing vasculitis) involved small veins, venules, and capillaries with necrosis, fibrin thrombi, and inclusion bodies within endothelial cells (Fig. 1E,F). Vasculitis was associated with hemorrhage, especially in the skin, gastrointestinal tract, and serosal surfaces of the viscera (Fig. 1G).

Of the toads that died later in the outbreak (June and July), 7 of 11 (64\%) had evidence of abscess formation in 1 or more sites including the skin, liver, kidney, spleen, pancreas, thymus, ovary, and Bidder's organ. Abscesses were composed of central aggregates of cellular debris admixed with degenerate neutrophils, macrophages, and a few eosinophils (Fig. 2). Many abscesses contained colonies of Gramnegative bacilliform bacteria. Stains for acid-fast bacteria and fungi were negative. In 4 toads, neutrophils and macrophages within abscesses had
Fig. 1. Histologic findings in zoo ranavirus (ZRV)-infected boreal toads Anaxyrus boreas boreas; slides stained with hematoxylin and eosin. (A) Early skin lesion with epidermal necrosis and vesicle formation (v). The arrow indicates an intracytoplasmic inclusion body. Scale bar $=30 \mu \mathrm{m}$. (B) More advanced skin lesion with full-thickness epidermal necrosis. Scale bar $=$ $0.5 \mathrm{~mm}$. (C) Necrosis of hematopoietic elements in bone marrow with intracytoplasmic inclusion bodies (arrow). Scale bar $=30 \mu \mathrm{m}$. (D) Necrosis of intravascular leukocytes suggested by karyorrhectic debris in sinusoids of the liver (arrows). There is also single-cell necrosis of hepatocytes (arrowhead). Scale bar $=60 \mu \mathrm{m}$. (E) Necrosis and fibrin thrombi in glomerular capillaries. Scale bar $=80 \mu \mathrm{m}$. (F) Endothelial cells in glomerular capillaries have intracytoplasmic inclusion bodies (arrows). Scale bar $=15 \mu \mathrm{m}$. (G) Small intestine with intraluminal hemorrhage. Scale bar $=350 \mu \mathrm{m}$
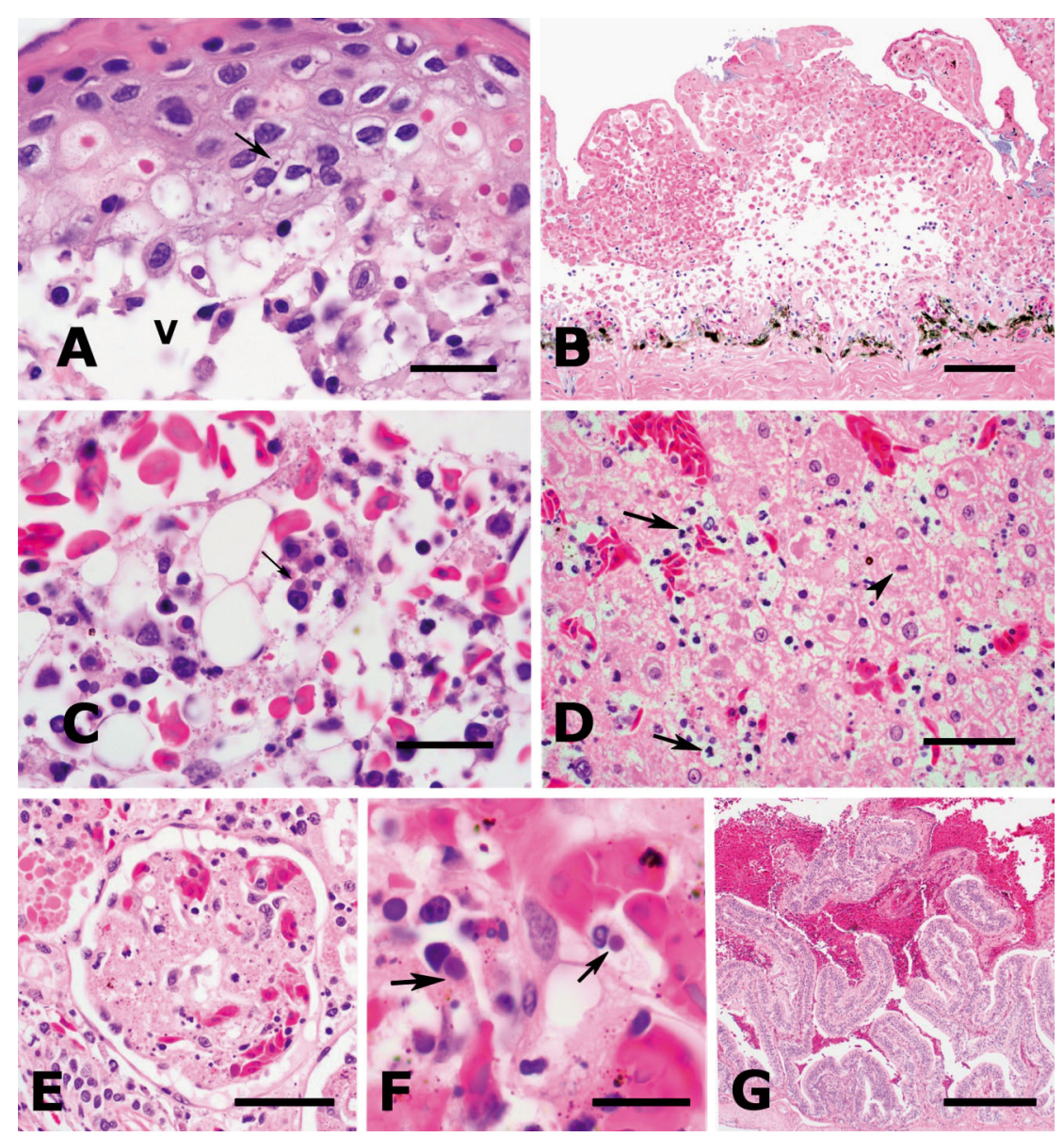


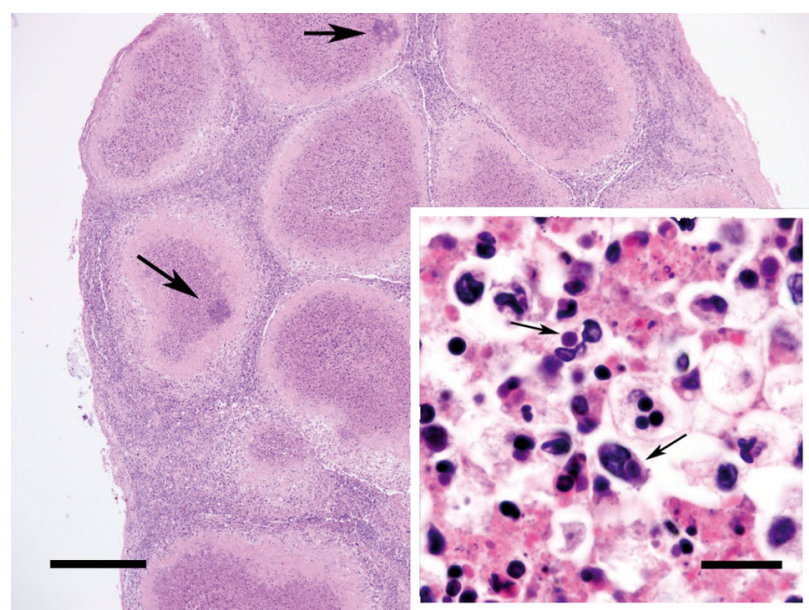

Fig. 2. Histology of the spleen from a boreal toad Anaxyrus boreas boreas with numerous abscesses that contain bacterial colonies (arrows). Scale bar $=0.5 \mathrm{~mm}$. Inset: Neutrophils (top) and macrophages (bottom) within abscesses have intracytoplasmic inclusion bodies (arrows). Stained with hematoxylin and eosin. Scale bar $=20 \mu \mathrm{m}$

intracytoplasmic basophilic inclusion bodies suggestive of ranavirus infection (Fig. 2, inset). None of the 5 surviving and apparently healthy boreal toads euthanized after the outbreak had lesions suggestive of a ranavirus infection.

\section{Transmission electron microscopy}

Transmission electron microscopy detected numerous icosahedral virions 138 to $153 \mathrm{~nm}$ in diameter typical of an iridovirus within the cytoplasm of renal tubular epithelial cells and epidermal keratinocytes (Fig. 3).

\section{Real-time PCR}

Ranaviral DNA was detected by real-time Taqman PCR from 6 of 6 oropharyngeal swabs (data not shown) and in 14 of 14 tissue samples from sick boreal toads collected during the outbreak (Table 1). Oropharyngeal swabs from 2 healthy Mantella viridis and 1 Megophrys nasuta were also positive during the time of the outbreak. In surviving boreal toads, 3 of 5 tissue samples $(60 \%)$ were positive $10 \mathrm{wk}$ after conclusion of the outbreak (Table 2). Tissue samples from sick toads contained considerably larger amounts of ranaviral DNA based on our observation of $\mathrm{Ct}$ values ranging from 10 to 15 compared to Ct values of 37 to 39 in surviving toads that tested positive.

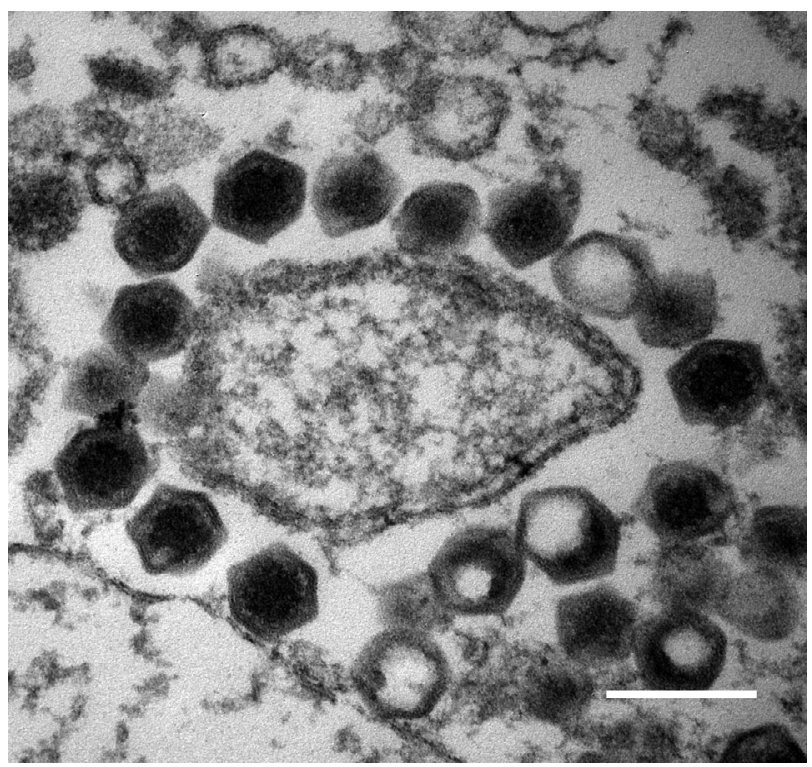

Fig. 3. Transmission electron micrograph identifying ranavirus particles in the kidney of an infected boreal toad Anaxyrus boreas boreas. The cytoplasm of a tubular epithelial cell contains numerous icosahedral particles typical of an iridovirus virion. Scale bar $=250 \mathrm{~nm}$

\section{Conventional PCR and DNA sequence analysis}

Conventional PCR targeting portions of the MCP, DNA pol, and NFP genes was successfully performed on tissues from boreal toad nos. 18 and 22, an oropharyngeal swab from $M$. nasuta, and tissue samples from an asymptomatic boreal toad and Melanophryniscus stelzneri collected $10 \mathrm{wk}$ after the end of the outbreak. In all samples, sequencing of the DNA pol and NFP amplicons demonstrated the highest level of sequence identity to BIV $(99.2 \%$ and $86.3 \%$, respectively), with lower levels of identity to other representative ranaviruses including ATV (97.7\% and $75.1 \%)$, EHNV (97.9\% and $74.4 \%)$, ECV $(98.3 \%$ and $65.4 \%)$, and FV3 (97.7\% and $78.3 \%)$. Sequencing of the MCP amplicon was less informative, showing $>99 \%$ identity with both BIV and a strain of FV3 designated Rana catesbeiana virus (RCV). These results indicate that boreal toads contained BIV-like DNA both during the acute phase of the outbreak and for at least $10 \mathrm{wk}$ afterwards. They also demonstrate that a few of the cohoused amphibians also contained BIV-like sequences both during the outbreak and $10 \mathrm{wk}$ after its conclusion.

\section{Virus isolation}

To better identify the causative agent, tissues from infected animals were homogenized to release virus, 
and the resulting clarified homogenate was used to infect FHM cells. Although no CPE was detected after an initial $7 \mathrm{~d}$ culture, a second blind passage resulted in marked CPE indicative of viral infection in 3 of 4 cultures. Virus prepared from 1 of these (designated ZRV) was used to prepare a viral stock for biochemical and genetic analysis.

\section{Viral protein profiles}

To compare viral protein profiles, FHM cells were mock-infected or infected with FV3 or ZRV, and protein synthesis was monitored by radiolabeling with $\left[{ }^{35}\right.$ S]methionine from 6 to $8 \mathrm{~h}$ p.i. Radiolabeled viral proteins were separated by electrophoresis on $10 \%$ SDS-polyacrylamide gels and visualized by phosphorimaging (Fig. 4). Mock-infected cells showed a range of radiolabeled proteins ranging in size from $>130$ $\mathrm{kDa}$ to $<17 \mathrm{kDa}$. Virus infection resulted, as expected, in a marked turn-off of cellular protein synthesis and the production of several characteristic viral proteins, chief among them the $48 \mathrm{kDa} \mathrm{MCP}$. Comparison of the profiles seen in FV3- and ZRV-infected cells showed them to be similar, with minor qualitative and quantitative differences. The protein profile supports classification of the putative infectious agent as a ranavirus, and the similarity of the FV3 and ZRV profiles is consistent with previous findings that members of the genus Ranavirus share many gene products in common (Mao et al. 1997, 1999a,b).

\section{RFLP analysis}

FV3 and ZRV genomic DNA were digested overnight with HindIII and separated by agarose gel electrophoresis. The resulting profiles (data not shown) were similar, but not identical, and consistent with the suggestion that ZRV is distinct from FV3 (Mao et al. 1997, 1999a, Weir et al. 2012). However, without a BIV reference sample, we could not definitively compare ZRV to BIV.

\section{Sequence analysis}

Genomic DNA was isolated from purified ZRV virions and sequenced using Illumina HiSeq 2000 technology. The resulting 62.6 million reads (encompassing 5322 million bases) were assembled, organized into 15 contigs totaling $102.1 \mathrm{kbp}$, and mapped to the FV3 genome. Assuming an average amphibian-like

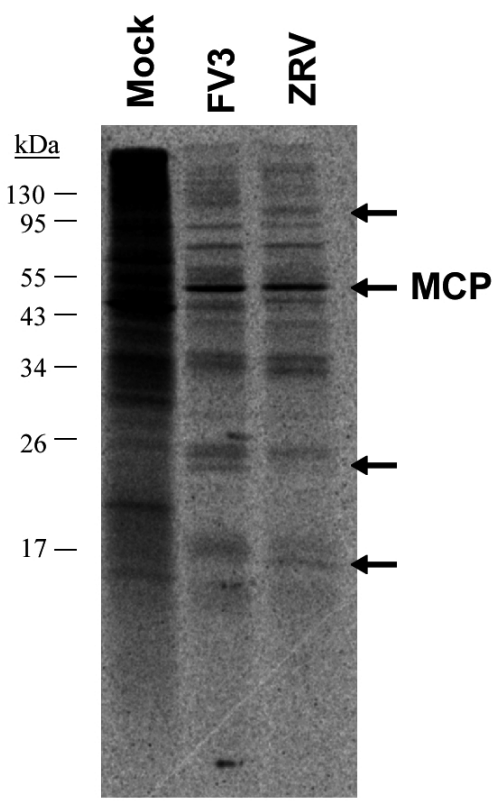

Fig. 4. SDS-polyacryamide gel analysis of viral protein synthesis in mock-, frog virus 3 (FV3)-, and zoo ranavirus (ZRV)-infected fathead minnow (FHM) cells. Radiolabeled infected cell lysates were examined by electrophoresis on $10 \%$ SDS-polyacrylamide gels, and viral proteins were visualized using a phosphorimager. The molecular weights of marker proteins are shown on the left side. On the right side, the viral MCP is indicated, as are 3 additional virus-induced proteins that differ in expression between FV3- and ZRVinfected cells

ranavirus (ALRV) genome size of $105 \mathrm{kbp}$ (Jancovich et al. 2010), we estimate that our sequence data accounts for $97 \%$ of the ZRV viral genome. To determine the taxonomic position of ZRV and other ranaviruses, we assessed levels of identity among a subset of BIV genes and the corresponding genes from ZRV and other ranaviruses (Table 3). For this study, we chose the $18 \mathrm{kDa}$ immediate-early protein (18K), the $46 \mathrm{kDa}$ immediate-early protein (46K), thymidine kinase (TK), and the viral MCP. Analyses of $18 \mathrm{~K}, 46 \mathrm{~K}$, $\mathrm{TK}$, and MCP indicated that all sequences showed marked identity, in most cases $>95 \%$, among the various ALRVs (data not shown). However, in all cases, the ZRV sequence most closely matched that of BIV. For example, percent identity of among the MCP proteins of ZRV and other ALRVs ranged from 100\% (BIV) to $96.5 \%$ (ATV). Markedly lower identities were seen with piscine ranaviruses $(83.6 \%$, largemouth bass virus [LMBV]; $73 \%$ GIV) and members of other iridovirus genera $(51 \%$, lymphocystis disease virus; $47.7 \%$, infectious kidney and spleen necrosis virus). Generation of individual phylogenetic trees for each of these genes supported the close association of ZRV and BIV (data not shown) as did construc- 
Table 3. Viral proteins used in multiple alignments and phylogenetic analysis. In addition to the viruses shown, the neurofilament proteins (NFPs) of soft shell turtle iridovirus (STIV, ACF42253.1) and Rana grylio virus (RGV, AFG 73076.1) were used in multiple alignment and phylogenetic tree construction. ATV: Ambystoma tigrinum virus; BIV: Bohle iridovirus; CMTV: common midwife toad virus; EHNV: epizootic hematopoietic necrosis virus; FV3: frog virus 3

\begin{tabular}{|c|c|c|c|c|c|}
\hline \multirow{2}{*}{ Gene } & \multicolumn{5}{|c|}{ Virus and GenBank accession numbers } \\
\hline & ATV & BIV & CMTV & EHNV & FV3 \\
\hline $\mathrm{MCP}$ & YP_003785.1 & ACO90022.1 & AFA44920.1 & ACO25204.1 & ACP19256.1 \\
\hline $18 \mathrm{~K}$ & YP_003794.1 & AAV97746.1 & AFA44929.1 & ACO25212.1 & YP_031661.1 \\
\hline $46 \mathrm{~K}$ & YP_003784.1 & AAV97747.1 & AFA44919.1 & ACO25203.1 & YP_031670.1 \\
\hline Thymidine kinase (TK) & YP_003790.1 & AAX39813.1 & AFA44925.1 & AAX39814.1 & YP_031664.1 \\
\hline NFP & YP_003834.1 & FJ391462.1 & AFA44982.1 & ACO25258.1 & YP_031610.1 \\
\hline
\end{tabular}

tion of a concatenated tree utilizing MCP, $18 \mathrm{~K}, 46 \mathrm{~K}$, and TK aa sequence data (Fig. 5). Collectively, phylogenetic analyses indicated that ZRV and BIV were linked (bootstrap value $=100 \%$ ).

Because the 4 ALRV genes analyzed above showed high levels of sequence identity, we sought to identify another viral gene that displayed more variability and which could be used to better differentiate among viral species and strains. Since earlier work indicated that the ranavirus NFP gene (corresponding to FV3 ORF32R) displayed considerable variability among isolates, we aligned ZRV NFP with that of other ALRV NFPs. It should be noted that the size of the NFP gene varies among different ALRVs due to the presence of multiple repeat regions. Moreover, the full length gene has not been identified in BIV and the only sequence data available for analysis is a 225 aa fragment from the C-terminal end of the protein. Determination of sequence identities within this 225 aa fragment indicated that ZRV displayed $98 \%$ identity to BIV and markedly lower identities to homologs from EHNV $(89.8 \%)$, FV3 (88.6\%), CMTV (87.8\%), and ATV $(82.9 \%)$. Examination of the alignment indicated that 2 repeat regions were present within the NFP fragment (Fig. 6). At the N-terminal end we detected a region of multiple KSP/RSP repeats, and at the C-terminal end we identified an 8 aa repeat (SQGGADYI) which is present 4 times in BIV but only once in the other ALRVs. As seen with the concatenated tree constructed using MCP, 18K, 46K, and TK sequence data, the tree generated using only NFP data confirmed the close association of BIV and ZRV (Fig. 7).

\section{DISCUSSION}

As described above, the high mortality of boreal toads within the survival assurance population was due to systemic ranavirus infection. Affected animals had histological lesions typical of a ranavirus infection, including multicentric organ and hematopoietic tissue necrosis and the presence of characteristic intracytoplasmic basophilic inclusion bodies. Supporting the histological findings were observation of iridovirus virions in affected tissues and PCR and DNA sequencing studies that identified a ranavirus (ZRV) closely related to BIV. Concurrent bacterial infections contributed to death in a subset of toads from this outbreak. Bacterial infections are well documented in ranavirus-infected anurans (Cunningham et al. 1996, Gray et al. 2009) and presumably result from disruption of normal epithelial barriers (e.g. virus-associated necrosis) or impaired immune function. Possible causes of immunosuppression secondary to ranaviral disease are hematopoietic tissue necrosis, which was a significant finding in these toads, or persistent infection of macrophages as described in experimental FV3 infections of Xenopus laevis (Morales et al. 2010). Although our results strongly suggest that ZRV was the etiological agent responsible for the observed die-

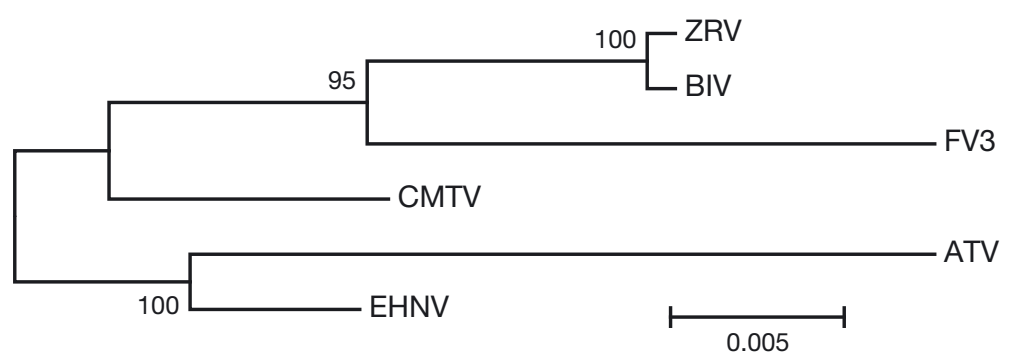

Fig. 5. Phylogenetic analysis of a concatenated set of 4 ranavirus protein sequences. Phylogeny was inferred using the maximum likelihood method within MEGA5 (Tamura et al. 2011). The analysis involved concatenation of 4 protein sequences (MCP, 18K, 46K, and TK) involving 1210 aa positions from select ranaviruses (see Table 3). All positions containing gaps and missing data were eliminated. See Fig. 7 for virus names 


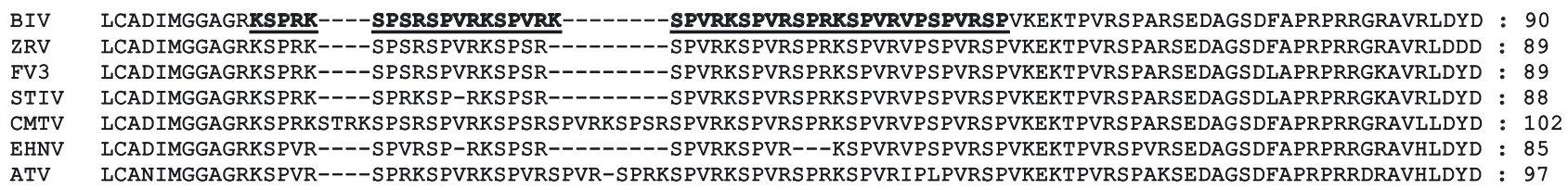

BIV EDDDYSYGASTDNLFSGYKEIPFPTRKRRTRKPEKVFVDVRLPHTLTDSEDEDDMVEVPELEDKEITRPGVLSPYSDKTFEREYI SQGGADYISQGGADYIS: 192 ZRV EDDDYSYGASTDNLFSGYKEIPFPTRKRRTRKPEKVFVDVRLPHTLTDSEDEDDMVEVPELEDKEITRPGVLSPYSDETFEREYISQG---------------: 177 FV3 EDDDYSYGASTDNLFSGNKEIPFPTRKRRTRKPEKVFVDVRSPHTLTDSEDEDDMVEVPELEDKEITMPGVLSPYSDEIVERGYVSQG--------------: 177 STIV EDDDYSYGASTDNLFYGNKEIPFPTRKRRTRKPEKVFVDVRSPHTLTDSEDEDDMVEVPELEDKEITMPGVLSPYSDD------VSOG--------------: 170 CMTV EDDDYSYGASTDNLFSGDKEIPFPTRKHRTRKPEKVFVDVRSPHTLTDSEDEDDMVEVPELEDKEITRPGVLSPYSDKTVERGYVSQG--------------: 190 EHNV EDD-YSYDASTDNLFSGDKEIPFPTRKRRTRKPKKVFADVRSPHTLTDSEDEDDMVEVPELEDKEITRPGVLSPY---------VSQG--------------: 163 ATV EDDDYSYDASTDNLFSGDNEIPFPVRKRRIREPKKVFVDVSSPHTLTDSEDEDDMVEVPELEDKEITRPGVLSPS---------VSOG--------------: 176

\begin{tabular}{|c|c|c|}
\hline BIV & QGGADYISQGGADYINYMYLTECALESDESFER: & \\
\hline RV & :--- GADY INYMYLTECALESDESFER: & 200 \\
\hline & IYRTEYALESDESFAR: & \\
\hline$I$ & --------GADYINYIYSTKYALESDESFAR: & \\
\hline$T$ & ---------GADYINYIYTTEYALESDKSFER: & \\
\hline & ---------GADYINYMYPTEYALESDESFER: & \\
\hline & -GADYINYIYSTEYALKSDEFFER: & \\
\hline
\end{tabular}

Fig. 6. Multiple alignment of the Bohle iridovirus (BIV) neurofilament protein (NFP) fragment and representative ranaviruses. A 225 aa fragment of BIV NFP along with corresponding regions from zoo ranavirus (ZRV), frog virus 3 (FV3), soft shell turtle iridovirus (STIV), common midwife toad virus (CMTV), epizootic hematopoietic necrosis virus (EHNV), and Ambystoma tigrinum virus (ATV) were aligned using the default parameters within the CLUSTAL W algorithm of DNASTAR. The KSP/RSP repeat region at the N-terminus and the SQGGADYI repeat at the C-terminus are indicated by underlined boldface type and italicized boldface type, respectively

off, Rivers's postulates were not fulfilled since we did not demonstrate that the isolated virus was able to trigger clinical disease when experimentally introduced into toads (Rivers 1937).

Although the high mortality seen in infected boreal toads is consistent with exposure to a recently introduced pathogen, we were unable to definitively identify the source of the infecting virus. For at least 1 yr prior to the outbreak, no new boreal toads or other amphibians were introduced into the holding room. Moreover, although the toad colony was maintained on its own water system, we cannot exclude the possibility of virus introduction via fomites from other amphibian species in the same room or fish housed in other areas within the facility. Supporting the possibility of virus transmission between amphib- ians is the identification of identical MCP, DNA pol, and NFP gene sequences among boreal toads, an asymptomatic Megophrys nasuta (sampled during the outbreak), and a Melanophryniscus stelzneri (assayed after the outbreak).

Alternatively, disease in the boreal toads could have resulted from a virus already present as a persistent subclinical infection within the toad colony (Brunner et al. 2004, Robert et al. 2005). Ranaviral disease is often seen in pre-metamorphic amphibians (tadpoles) whose immune systems are not fully developed or in adult animals subjected to stress that triggers immune suppression (Tweedell \& Granoff 1968, Gantress et al. 2003). In addition, environmental conditions such as temperature can influence disease progression as shown in experimental ranavirus

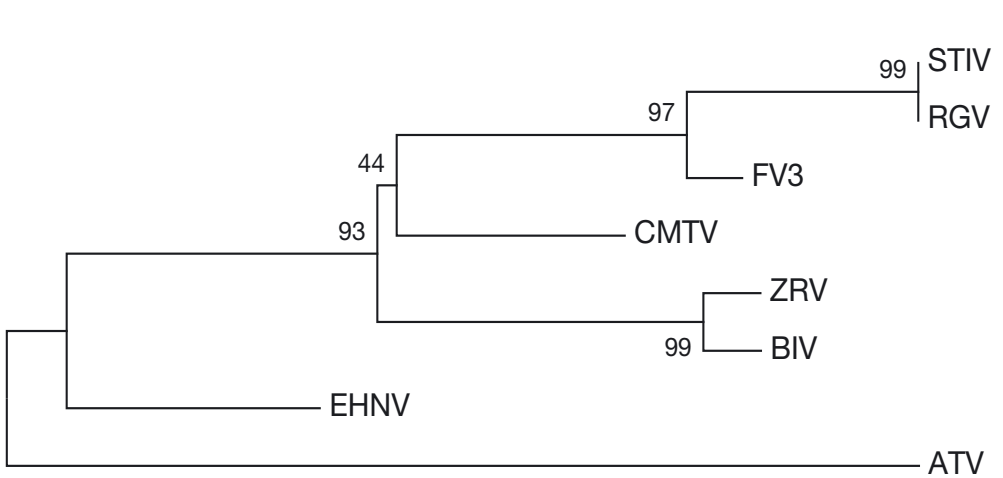

$\longmapsto$
Fig. 7. Phylogenetic analysis of ranavirus neurofilament protein sequences. Alignment of a 225 aa fragment of the neurofilament protein (NFP) from soft shell turtle virus (STIV), Rana grylio virus (RGV), frog virus 3 (FV3), common midwife toad virus (CMTV), zoo ranavirus (ZRV), Bohle iridovirus (BIV), epizootic hematopoietic necrosis virus (EHNV), and Ambystoma tigrinum virus (ATV) was performed using the MUSCLE algorithm within MEGA5 (Tamura et al. 2011). Based on that alignment, a phylogenetic tree was constructed using the maximum likelihood method. All positions containing gaps and missing data were eliminated, resulting in a total of 186 aa positions in the final data set. Accession numbers of the ranaviruses used in this analysis are shown in Table 3 
infections of tiger salamanders and red-eared slider turtles (Rojas et al. 2005, Allender et al. 2013). In the case of the boreal toads, the possibility that subclinical infection could occur with ZRV is suggested by the observation that 3 of 5 asymptomatic boreal toads euthanized after conclusion of the outbreak had PCR evidence of persistent viral DNA. However, the affected boreal toads in this outbreak were not exposed to any known stressor (e.g. poor water quality, overcrowding, or temperature change) that might explain the development of fulminant infection.

Collectively, our results support the view that ZRV is most similar to BIV and also suggest that a revision of ranavirus taxonomy should be considered because geographic and host range cannot be considered as truly unique identifiers of ranavirus species. Perhaps ranavirus species would be better characterized by phylogenetic analyses employing a concatenated set of viral genes to determine lineage and dot plot analyses of whole genomes to ascertain gene order. The consequences of this revision would likely be a reduction in the number of ranavirus species. Designations such as ZRV may be retained for historical value and/or identification purposes, but such viruses would now be considered as strains or isolates of an established species such as BIV.

Although this is the first report of a BIV-like virus outside of Australia, we do not know whether ZRV represents a novel North American variant or is a virus introduced into the boreal toads from other animals housed within the aquarium facility that originated from another geographical region. As with other iridoviruses that were once thought confined to distinct geographical regions, subsequent study has shown that these viruses can display widespread distribution. For example, LMBV, originally detected in the southeastern USA (Plumb et al. 1999), is now known to be present throughout a large portion of the USA and has subsequently been detected in Asia (Deng et al. 2011). Likewise, megalocytiviruses, originally detected in Southeast Asia, have now been identified in Australia and North America, possibly because of introduction via the ornamental fish trade (Go et al. 2006, Go \& Whittington 2006). Although of a smaller magnitude than ornamental fish, wildcaught amphibians such as $M$. nasuta co-housed with the boreal toads (Wildenhues et al. 2012) are moved internationally for trade, so the possibility of isolated introductions of geographically novel ranaviruses cannot be excluded in these situations.

Because routine surveys for ranavirus infection are often limited to PCR and sequence analysis of part of the MCP gene, it is possible that animals infected with BIV-like viruses have been previously overlooked. For instance, because ZRV demonstrated $>99 \%$ identity with MCP to both BIV and FV3, BIV infections might have been attributed to FV3. This would also have been the case with the current outbreak had not sequence analysis of the DNA polymerase and NFP genes also been performed. Similarly, it is increasingly recognized that ranavirus isolates with distinct restriction enzyme profiles have virtually identical MCP gene sequences (Schock et al. 2008, Duffus \& Andrews 2013). Ideally, future surveys of wild and captive amphibian populations for ranaviruses should be coupled with more extensive genotyping in order to determine the true distribution of distinct FV3- and BIV-like ranaviruses.

In the future, rapid identification of the specific ranavirus responsible for a given disease outbreak may rely on sequence analysis of the NFP gene. The designation of this gene product as a neurofilament protein reflects the presence of multiple copies of the KSP aa triplet, a motif present within collagen and a target for serine phosphorylation (Carpenter \& Ip 1996). Although the specific function of the ranavirus NFP is not known, the presence of repeat regions of various sizes suggests that it may be a good target for distinguishing ranavirus species and strains based on size and sequence differences.

In conclusion, the ranavirus outbreak in this survival assurance population was worrisome because of the high mortality ( $>90 \%$ ) and detection of low levels of ZRV DNA in surviving toads 10 wk after the last observed death. Although detection of ZRV DNA in these animals does not prove a persistent ranaviral infection, the observation does raise concern that a virulent and geographically novel ranavirus could have been released into wild boreal toad populations as the result of a future reintroduction program. Moreover, if ZRV was introduced into the boreal toad population from another amphibian species housed in the same facility, this example of 'pathogen pollution' would support recommendations to house survival assurance populations in isolation from other amphibians (Pessier 2008, Pessier \& Mendelson 2010).

Acknowledgements. This project was supported by award LG-25-08-0066 from the Institute of Museum and Library Services and National Science Foundation award IOS-0742711. Any views, findings, conclusions or recommendations expressed in this publication do not necessarily represent those of the Institute for Museum and Library Services. We thank Kristin Benson, Yvonne Cates, Isa Navarrete, and Lee Jackson for their support of this project. We also thank Dr. Wei Yu for assistance in assembly of the ZRV genome. 


\section{LITERATURE CITED}

Allender MC, Mitchell MA, Torres T, Sekowska J, Driskell EA (2013) Pathogenicity of Frog Virus 3-like virus in redeared slider turtles (Trachemys scripta elegans) at two environmental temperatures. J Comp Pathol 149:356-367

Altschul SF, Gish W, Miller W, Myers EW, Lipman DJ (1990) Basic local alignment search tool. J Mol Biol 215:403-410

Bollinger TK, Mao J, Schock D, Brigham RM, Chinchar VG (1999) Pathology, isolation, and preliminary molecular characterization of a novel iridovirus from tiger salamanders in Saskatchewan. J Wildl Dis 35:413-429

> Brunner JL, Schock DM, Davidson EW, Collins JP (2004) Intraspecific reservoirs: complex life history and the persistence of a lethal ranavirus. Ecology 85:560-566

Carpenter DA, Ip W (1996) Neurofilament triplet protein interactions: evidence for the preferred formation of NFL-containing dimers and a putative function for the end domains. J Cell Sci 109:2493-2498

> Chinchar VG (2002) Ranaviruses (family Iridoviridae): emerging cold-blooded killers. Arch Virol 147:447-470

- Chinchar VG, Waltzek TB (2014) Ranaviruses: not just for frogs. PLoS Pathog 10:e1003850

Chinchar VG, Hyatt A, Miyazaki T, Williams T (2009) Family Iridoviridae: poor viral relations no longer. Curr Top Microbiol Immunol 328:123-170

Chinchar VG, Robert J, Storfer AT (2011) Ecology of viruses infecting ectothermic vertebrates - the impact of ranavirus infections on amphibians. In: Hurst CJ (ed) Studies in viral ecology. Wiley-Blackwell, Hoboken, NJ, p 231-259

> Cullen BR, Owens L (2002) Experimental challenge and clinical cases of Bohle iridovirus (BIV) in native Australian anurans. Dis Aquat Org 49:83-92

Cunningham AA, Langton TE, Bennett PM, Lewin JF, Drury SE, Gough RE, Macgregor SK (1996) Pathological and microbiological findings from incidents of unusual mortality of the common frog (Rana temporaria). Philos Trans R Soc Lond B Biol Sci 351:1539-1557

Cunningham AA, Hyatt AD, Russell P, Bennett PM (2007a) Emerging epidemic diseases of frogs in Britain are dependent on the source of ranavirus agent and the route of exposure. Epidemiol Infect 135:1200-1212

> Cunningham AA, Hyatt AD, Russell P, Bennett PM (2007b) Experimental transmission of a ranavirus disease of common toads (Bufo bufo) to common frogs (Rana temporaria). Epidemiol Infect 135:1213-1216

Deng G, Li S, Xie J, Bai J and others (2011) Characterization of a ranavirus isolated from cultured largemouth bass (Micropterus salmoides) in China. Aquaculture 312: 198-204

> Docherty DE, Meteyer CU, Wang J, Mao J, Case ST, Chinchar VG (2003) Diagnostic and molecular evaluation of three iridovirus-associated salamander mortality events. J Wildl Dis 39:556-566

> Driskell EA, Miller DL, Swist SL, Gyimesi ZS (2009) PCR detection of ranavirus in adult anurans from the Louisville Zoological Garden. J Zoo Wildl Med 40:559-563

$>$ Duffus AL, Andrews AM (2013) Phylogenetic analysis of a frog virus 3-like ranavirus found at a site with recurrent mortality and morbidity events in southeastern Ontario, Canada: partial major capsid protein sequence alone is not sufficient for fine-scale differentiation. J Wildl Dis 49: 464-467

> Fox SF, Greer AL, Torres-Cervantes R, Collins JP (2006) First case of ranavirus-associated morbidity and mortal- ity in natural populations of the South American frog Atelognathus patagonicus. Dis Aquat Org 72:87-92

Gantress J, Maniero GD, Cohen N, Robert J (2003) Development and characterization of a model system to study amphibian immune responses to iridoviruses. Virology 311:254-262

> Geng Y, Wang KY, Zhou ZY, Li CW, and others (2011) First report of a ranavirus associated with morbidity and mortality in farmed Chinese giant salamanders (Andrias davidianus). J Comp Pathol 145:95-102

Go J, Whittington R (2006) Experimental transmission and virulence of a megalocytivirus of dwarf gourami (Colisa lalia) from Asia in Murray cod (Maccullochella peelii peelii). Aust Aquacult 258:140-149

> Go J, Lancaster M, Deece K, Dhungyel O, Whittington R (2006) The molecular epidemiology of iridovirus in Murray cod (Maccullochella peelii peelii) and dwarf gourami (Colisa lalia) from distant biogeographical regions suggests a link between trade in ornamental fish and emerging iridoviral diseases. Mol Cell Probes 20:212-222

Granoff A, Came PE, Rafferty KA Jr (1965) The isolation and properties of viruses from Rana pipiens: their possible relationship to the renal adenocarcinoma of the leopard frog. Ann NY Acad Sci 126:237-255

Granoff A, Came PE, Breeze DC (1966) Viruses and renal carcinoma of Rana pipiens. I. The isolation and properties of virus from normal and tumor tissue. Virology 29: 133-148

Gray MJ, Miller DL, Hoverman JT (2009) Ecology and pathology of amphibian ranaviruses. Dis Aquat Org 87:243-266

Green DE, Converse KA, Schrader AK (2002) Epizootiology of sixty-four amphibian morbidity and mortality events in the USA 1996-2001. Ann NY Acad Sci 969:323-339

- Holopainen R, Ohlemeyer S, Schütze H, Bergmann SM, Tapiovaara H (2009) Ranavirus phylogeny and differentiation based on major capsid protein, DNA polymerase and neurofilament triplet H1-like protein genes. Dis Aquat Org 85:81-91

Huang Y, Huang X, Liu H, Gong J and others (2009) Complete sequence determination of a novel reptile iridovirus isolated from soft-shelled turtle and evolutionary analysis of Iridoviridae. BMC Genomics 10:224

> Hyatt AD, Gould AR, Zupanovic Z, Cunningham AA and others (2000) Comparative studies of piscine and amphibian iridoviruses. Arch Virol 145:301-331

> Jancovich JK, Davidson EW, Morado JF, Jacobs BL, Collins JP (1997) Isolation of a lethal virus from the endangered tiger salamander Ambystoma tigrinum stebbinsi. Dis Aquat Org 31:161-167

> Jancovich JK, Bremont M, Touchman JW, Jacobs BL (2010) Evidence for multiple recent host species shifts among the ranaviruses (family Iridoviridae). J Virol 84:2636-2647

Jancovich JK, Chinchar VG, Hyatt A, Miyazaki T and others (2012) Family Iridoviridae. In: King AMQ, Adams MJ, Carstens EB, Lefkowitz EJ (eds) Virus taxonomy: classification and nomenclature of viruses. Ninth Report of the International Committee on Taxonomy of Viruses. Elsevier, Amsterdam, p 193-210

Johnson AJ, Pessier AP, Wellehan JF, Childress A and others (2008) Ranavirus infection of free-ranging and captive box turtles and tortoises in the United States. J Wildl Dis 44:851-863

$>$ Laemmli UK (1970) Cleavage of structural proteins during the assembly of the head of bacteriophage T4. Nature 227:680-685 
Larkin MA, Blackshields G, Brown NP, Chenna R and others (2007) Clustal W and Clustal X version 2.0. Bioinformatics 23:2947-2948

Majji S, LaPatra S, Long SM, Sample R, Bryan L, Sinning A, Chinchar VG (2006) Rana catesbeiana virus Z (RCV-Z): a novel pathogenic ranavirus. Dis Aquat Org 73:1-11

Mao J, Hedrick RP, Chinchar VG (1997) Molecular characterization, sequence analysis, and taxonomic position of newly isolated fish iridoviruses. Virology 229:212-220

> Mao J, Green DE, Fellers G, Chinchar VG (1999a) Molecular characterization of iridoviruses isolated from sympatric amphibians and fish. Virus Res 63:45-52

> Mao J, Wang J, Chinchar GD, Chinchar VG (1999b) Molecular characterization of a ranavirus isolated from largemouth bass Micropterus salmoides. Dis Aquat Org 37: 107-114

Mavian C, Lopez-Bueno A, Balseiro A, Casais R, Alcami A, Alejo A (2012) The genome sequence of the emerging common midwife toad virus identifies an evolutionary intermediate within ranaviruses. J Virol 86:3617-3625

Mazzoni R, de Mesquita AJ, Fleury LFF, de Brito WMED and others (2009) Mass mortality associated with a frog virus 3-like Ranavirus infection in farmed tadpoles Rana catesbeiana from Brazil. Dis Aquat Org 86:181-191

Miller DL, Rajeev S, Gray MJ, Baldwin CA (2007) Frog virus 3 infection, cultured American bullfrogs. Emerg Infect Dis 13:342-343

Miller DL, Rajeev S, Brookins M, Cook J, Whittington L, Baldwin CA (2008) Concurrent infection with ranavirus, Batrachochytrium dendrobatidis, and Aeromonas in a captive anuran colony. J Zoo Wildl Med 39:445-449

Moody NJG, Owens L (1994) Experimental demonstration of pathogenicity of a frog virus, Bohle iridovirus, for a fish species, barramundi Lates calcarifer. Dis Aquat Org 18: 95-102

> Morales HD, Abramowitz L, Gertz J, Sowa J, Vogel A, Robert J (2010) Innate immune responses and permissiveness to ranavirus infection of peritoneal leukocytes in the frog Xenopus laevis. J Virol 84:4912-4922

Pallister J, Gould A, Harrison D, Hyatt A, Jancovich J, Heine H (2007) Development of real-time PCR assays for the detection and differentiation of Australian and European ranaviruses. J Fish Dis 30:427-438

Pasmans F, Blahak S, Martel A, Pantchev N, Zwart P (2008) Ranavirus-associated mass mortality in imported red tailed knobby newts (Tylototriton kweichowensis): a case report. Vet J 176:257-259

Pessier AP (2008) Management of disease as a threat to amphibian conservation. Int Zoo Yearb 42:30-39

Pessier AP, Mendelson JR (2010) A manual for control of infectious diseases in amphibian survival assurance colonies and reintroduction programs. IUCN/SSC Conservation Breeding Specialist Group, Apple Valley, MN

Plumb JA, Noyes AD, Graziano S, Wang J, Mao J, Chinchar VG (1999) Isolation and identification of viruses from adult largemouth bass during a 1997-1998 survey in the southeastern United States. J Aquat Anim Health 11: 391-399

Rivers TM (1937) Viruses and Koch's Postulates. J Bacteriol 33:1-12

Editorial responsibility: Alex Hyatt, Victoria, Geelong, Australia
Robert J, Morales H, Buck W, Cohen N, Marr S, Gantress J (2005) Adaptive immunity and histopathology in frog virus 3-infected Xenopus. Virology 332:667-675

Rojas S, Richards K, Jancovich JK, Davidson EW (2005) Influence of temperature on Ranavirus infection in larval salamanders Ambystoma tigrinum. Dis Aquat Org 63: 95-100

Schloegel LM, Daszak P, Cunningham AA, Speare R, Hill B (2010) Two amphibian diseases, chytridiomycosis and ranaviral disease, are now globally notifiable to the World Organization for Animal Health (OIE): an assessment. Dis Aquat Org 92:101-108

Schock DM, Bollinger TK, Chinchar VG, Jancovich JK, Collins JP (2008) Experimental evidence that amphibian ranaviruses are multihost pathogens. Copeia 2008: 133-143

Song WJ, Qin QW, Qiu J, Huang CH and others (2004) Functional genomics analysis of Singapore grouper iridovirus: complete sequence determination and proteonomic analysis. J Virol 78:12576-12590

Speare R, Smith JR (1992) An iridovirus-like agent isolated from the ornate burrowing frog Limnodynastes ornatus in northern Australia. Dis Aquat Org 14:51-57

Tamura K, Peterson D, Peterson N, Stecher G, Nei M, Kumar S (2011) MEGA5: molecular evolutionary genetics analysis using maximum likelihood, evolutionary distance, and maximum parsimony methods. Mol Biol Evol 28: 2731-2739

Teacher AGF, Cunningham AA, Garner TWJ (2010) Assessing the long-term impact of ranavirus infections on wild common frog (Rana temporaria) populations. Anim Conserv 13:514-522

- Tweedell K, Granoff A (1968) Viruses and renal carcinoma of Rana pipiens. V. Effect of frog virus 3 on developing frog embryos and larvae. J Natl Cancer Inst 40:407-410

Weir RP, Moody NJG, Hyatt AD, Crameri S, Voysey R, Pallister J, Jerrett IV (2012) Isolation and characterisation of a novel Bohle-like virus from two frog species in the Darwin rural area, Australia. Dis Aquat Org 99:169-177

> Weng SP, He JG, Wang XH, Lu L, Deng M, Chan SM (2002) Outbreaks of an iridovirus disease in cultured tiger frog, Rana tigrina rugulosa, in southern China. J Fish Dis 25: 423-427

Wildenhues M, Rauhaus A, Bach R, Karbe D, van der Straeten K, Hertwig ST, Ziegler T (2012) Husbandry, captive breeding, larval development and stages of the Malayan horned frog Megophrys nasuta (Schlegel, 1858) (Amphibia: Anura: Megophryidae). Amphib Reptile Conserv 5:15-28

- Wolf K, Bullock GL, Dunbar CE, Quimby MC (1968) Tadpole edema virus: a viscerotropic pathogen for anuran amphibians. J Infect Dis 118:253-262

> Zhang QY, Xiao F, Li ZQ, Gui JF, Mao J, Chinchar VG (2001) Characterization of an iridovirus from the cultured pig frog Rana grylio with lethal syndrome. Dis Aquat Org 48: 27-36

Zippel K, Johnson K, Gagliardo R, Gibson R and others (2011) The amphibian ark: a global community for exsitu conservation of amphibians. Herpetol Conserv Biol 6:340-352

Submitted: November 4, 2013; Accepted: May 25, 2014 Proofs received from author(s): August 20, 2014 